\title{
Web-based survey usefulness for studying the influence of school bags and backpacks on back and neck pain in children and adolescents - pilot study in a medium-sized town
}

\author{
Wojciech Glinkowski", Izabela Czyżak, Bożena Glinkowska, Agnieszka Żukowska \\ From 10th International Conference on Conservative Management of Spinal Deformities - SOSORT 2013 \\ Annual Meeting \\ Chicago, IL, USA. 8-11 May 2013
}

\section{Background}

The frequent use of websites by today's education programs provides greater opportunities for surveying children and adolescents on health-related issues, including back pain. The prevalence of nonspecific back pain increases during adolescence [1-3]. There are several reasons for this increase in back pain in adolescents.

\section{Purpose}

The aim of the study was to use a web-based surveying system to investigate the possible connection between back pain in adolescents and the use of bags or backpacks.

\section{Methods}

The study was conducted in a town of almost 50,000 residents in north-central Poland. A cross-sectional study consisted of a web-based survey with modified questionnaire that was distributed to five schools along with an official recommendation by local authorities.

\section{Results}

A total of 380 questionnaires were submitted with no logical errors and highly probable answers from 220 girls (average age 13.4 years old) and 160 boys (average age 13.7 years old). The back and neck pain was mentioned by $49 \%$ of adolescents ( $51 \%$ of girls and $46 \%$ of boys). Thoracic and lumbar pain was mentioned by 39 girls $(10 \%)$ and 100 boys (26\%). The reported pain occurred

\footnotetext{
* Correspondence: w.glinkowski@gmail.com

Chair and Department of Orthopaedics and Traumatology of Locomotor System, Center of Excellence "TeleOrto", Baby Jesus Clinical Hospital, Medical University of Warsaw, Poland
}

intermittently (72.5\%), mostly during the day (63\%). Some respondents mentioned that pain occurs when they carry their bags on their shoulders (7\%) or when they carry their backpacks (19\%). Girls more likely carry bags (youth style), and boys prefer backpacks or rucksacks. Girls usually carry bags on the same shoulder. Of the total respondents, $65 \%$ were pain-free while being physically active $2-4$ hours per week outside of the school physical education program $(\mathrm{p}<0,01)$.

\section{Conclusions and discussion}

Our study confirms the usefulness of the web-based survey for children and adolescents. In addition, we discovered a relatively high prevalence of back and neck pain in adolescents, with girls experiencing pain significantly more frequently than boys. Compared with adolescents who had no back pain, adolescents with back pain carried significantly heavier backpacks that represented a significantly greater percentage of their body weights.

\section{Published: 18 September 2013}

\section{References}

Negrini S, Carabalona R, Sibilla P: Backpack as a daily load for schoolchildren. Lancet 1999, 354:1974.

2. Rodriguez-Oviedo P, Ruano-Ravina A, Perez-Rios M, Garcia FB, GomezFernandez D, Fernandez-Alonso A, et al: School children's backpacks, back pain and back pathologies. Archives of disease in childhood 2012, 97:730-2.

3. Korovessis P, Koureas G, Papazisis Z: Correlation between backpack weight and way of carrying, sagittal and frontal spinal curvatures, athletic activity, and dorsal and low back pain in schoolchildren and adolescents. J Spinal Disord Tech 2004, 17:33-40. 
doi:10.1186/1748-7161-8-S2-043

Cite this article as: Glinkowski et al: Web-based survey usefulness for studying the influence of school bags and backpacks on back and neck pain in children and adolescents - pilot study in a medium-sized town. Scoliosis 2013 8(Suppl 2):O43.

Submit your next manuscript to BioMed Central and take full advantage of:

- Convenient online submission

- Thorough peer review

- No space constraints or color figure charges

- Immediate publication on acceptance

- Inclusion in PubMed, CAS, Scopus and Google Scholar

- Research which is freely available for redistribution

Submit your manuscript at www.biomedcentral.com/submit
Ciomed Central 